'Sufurias cannot bring blessings': change, continuity and resilience in the world of Marakwet pottery, a case from western Kenya

Samuel F. Derbyshire ${ }^{a^{*}}$, Henrietta L. Moore ${ }^{\mathrm{b}}$, Helena Cheptoo $^{\mathrm{c}}$, Matthew I.J. Davies ${ }^{\mathrm{d}}$

${ }^{\mathrm{a}}$ Pitt Rivers Museum, University of Oxford, Oxford, UK; ${ }^{\mathrm{b}}$ Director, Institute for Global Prosperity, University College London, UK; ${ }^{c}$ Marakwet Research Station, Tot, Kenya; ${ }^{\mathrm{d}}$ Institute for Global Prosperity, University College London, London, UK.

*Samuel.derbyshire@sjc.ox.ac.uk 


\title{
'Sufurias cannot bring blessings': change, continuity and resilience in the world of Marakwet pottery, a case from western Kenya
}

\begin{abstract}
Drawing on fieldwork conducted over multiple seasons between 2012 and 2015, this paper explores aspects of the socio-economic and political history of the Marakwet of Kenya. It does so by focusing on a particular material culture category — pottery and tracing transformations in its production, use and exchange over several generations from the early $20^{\text {th }}$ century to the present day. This approach serves to unearth a series of personal and quotidian narratives that not only comprise a unique account of Marakwet's past, but also shed light on the material consequences of various ongoing processes of infrastructural and economic development. Complementing our previous work on Marakwet farming, landscape and ecological change, we here demonstrate the multiple ways in which change has been dynamically negotiated and enacted throughout the last century via various shifting daily practices. The historical innovations, adaptations and movements that we explore attest to a resilience deeply rooted in Marakwet society that continues to be articulated in the contemporary world.
\end{abstract}

Keywords: Pottery; material culture; Marakwet; Kenya; resilience; history; archaeology; anthropology

\section{Introduction}

Walking amongst the houses of Sibou, in the Marakwet region of western Kenya, one notices a mixture of broken upturned clay pots, plastic containers and deep sided aluminium sufuria cooking vessels lodged on the tops of many of the conical thatched roofs. This assortment of rooftop containers is a reflection of what can generally be found within kitchens and homes across Marakwet. Over the last few decades, plastic containers and aluminium cooking pots have become increasingly ubiquitous; today 
they are regularly purchased from local markets and used to perform a range of domestic functions that had previously been fulfilled solely by locally-made clay pots. The arrival of these new materials and other consumer products, which is explored in detail in Moore's early work in the region, ${ }^{1}$ has, over the years, coincided with the gradual disappearance of the once-common activity of pottery production. In 2015, an elderly ex-potter explained that:

"Endo people put them there for two reasons; one is that they stop the wind blowing the thatch away, but they are also there to bring blessings upon those inside... In the past it was only pots, the ones that had already been broken, we would wash them and put them up there, and usually the ones that were very old... pots are able to last a lifetime and they are blessed many times in life. Today, people put both pots and sufurias [on houses], but sufurias cannot bring blessings because they have not been blessed in the past - they are only there to hold the thatch".

Are these plastic and aluminium containers representative of dramatic social change? In her 1984 doctoral thesis Alice Welbourn argued that the symbolic value that pots comprise in these contexts is far more important than their functional role. ${ }^{2}$ Does this suggest that the use of plastic and aluminium containers signifies the erosion of past values and practices for the Marakwet? The notion of blessings disappearing as pots are replaced by 'novel' materials certainly conjures a sense of nostalgia and urgency — what will happen when there are no more blessings pouring down upon the families of Sibou? Or perhaps these questions reflect an inaccurate perception of the situation for there is, on the other hand, an equally clear impression of continuity to be apprehended. We might instead ask whether these plastic and metal containers would be placed on roofs at all if there were no history of pots performing this role in the past. Indeed, if the practice of placing pots, whether clay or otherwise, on top of thatched roofs has endured despite the incursion of new materials can we read the situation as reflecting a kind of cultural resilience in the face of broader economic and political transformations? Are these new items in fact performing as reimagined versions of clay pots in a new context? And if so, do they therefore comprise a temporality that is not necessarily contingent on their material duration, but rather the historical practices and processes that they articulate in their performance? 
Underlying these seemingly incongruent questions is the fact that, in Sibou, change and continuity are not mutually exclusive but rather entangled in complex and nuanced ways. ${ }^{3}$ It is perhaps self-evident that the recent large-scale incursion of a range of new materials and consumer products into the Marakwet region has had, and will continue to have, multiple repercussions for the various processes of production, use and exchange that have historically comprised the world of pottery (including the act of placing broken vessels on rooftops). However, interpreting the significance of this course of change in relation to broader social values, institutions and grounded livelihood practices is far from straightforward. Indeed, in the above case, focusing exclusively on the changing forms and materials of rooftop containers without considering the broader social contexts in which they perform serves only to obscure an understanding of, for example, the significant relationship between changing Marakwet familial structures, intimate domestic practices and the transforming layout of Marakwet compounds and households. ${ }^{4}$

Therefore, in this article we do not explore aspects of Marakwet history by envisioning material changes or 'replacements' through time as representative or reflective of changing cultural codes and meanings. Instead, we do so by taking into account the gradually but constantly shifting ways in which a wide range of activities and practices relating to the world of pottery have been reconfigured and adapted by the Sibou community in the continual production of contexts where such meanings may be invoked. A key notion underpinning our analysis is that everyday things cannot be fully comprehended in relation to a single point, or event, in time but rather, as implied by Arjun Appadurai, are bound up in long and complex histories of successive re-contextualisation. ${ }^{5}$ We suggest that an examination of these narratives of change and continuity in material culture, and their integration with explorations of contemporary life and engagements with new technologies and materials, are an essential means of moving beyond still-common and somewhat pessimistic conceptualisations of recent socio-economic change in Marakwet (along with various other rural African societies) as the loss of past life-ways and supposedly static traditions. $^{6}$ 
Our concentration on pottery in this article also corresponds more broadly with the fact that material culture has, particularly in the last few decades, come to be a critical focus of analysis across the social sciences, stimulating the development of a diverse assortment of theories and ideas concerning the mutual interactions that connect people and their material worlds, and how this interplay shapes the field of social action through time. ${ }^{7}$ Arguably one of the most enduringly prominent of these ideas is that of objectification, as developed in a range of contexts and case studies that draw on Hegel's initial characterisation of the term. Over the past few decades, objectification has come to be understood as the fundamental process whereby both material and social worlds are produced in a mutually constitutive manner. In other words, identities, social institutions, value systems and practices do not serve to manufacture objects in a straightforward sense but are rather themselves also constituted by the production, use and consumption of material things. Subjects and objects - the conscious and the material - are the remnants that surface 'in the wake' of the always-advancing and always-integral process of objectification. ${ }^{8}$

Being grounded in the changing patterns of production, consumption and exchange that encompass the world of Marakwet pottery, the account of recent history that we outline in this article has inevitably taken form through a broad interest in the objectification processes that structure everyday life in the region. In adopting this viewpoint, one of our basic hopes is to demonstrate the capacity it grants for moving beyond the superficial discontinuities and ruptures that otherwise appear to be indexed in the transforming materiality of everyday life in many rural, nonindustrialised parts of the world (particularly in association with the apparentlyexponential process of globalisation). What we mean by this is that in order to think through the deceptive and stubborn tradition/modernity dualism, and to avoid falling back on a view of social change in such parts of the world as the inexorable disintegration of the former in the establishment of the latter, our discussion is rooted in the assumption that all of the objects in-play in Marakwet have come to be both symbolically and pragmatically constituted through their positions and activities within Marakwet society, irrespective of the location of their initial construction (i.e. whether they are produced locally or further afield) and the materials of which they are composed. 
In this sense, our exploration of the socio-economic, ecological and political trajectories that have been negotiated both by and with the artefacts and materials that have come to be entangled in the world of Marakwet pottery also correlates with socalled 'biographical' approaches to objects. ${ }^{9}$ These approaches have predominantly sought to develop ideas which were established in Appadurai's volume The social life of things: commodities in cultural perspective. Igor Kopytoff's contribution to this volume, which explored commoditization as a fluid cognitive and cultural process and outlined the open-ended and changeable nature of the statuses ascribed to various objects as they move between people, places and phases of degradation, is particularly key to understanding pottery in Marakwet. ${ }^{10}$ Whilst we do not have space to consider them at length in this article, the relevance of Kopytoff's points should become clear as our argument develops.

Since the publication of The Social Life of Things, a view of objectification that deemphasises production has come to be widely adopted in examinations of sociomaterial relations that are undertaken via the theme of biography, as has a much broader conceptualisation and use of the term 'biography'. Janet Hoskins summarises these points by commenting that "things can be said to have "biographies" as they go through a series of transformations from gift to commodity to inalienable possessions, and persons can also be said to invest aspects of their own biographies on things'. ${ }^{11}$ In this article, we approach questions of change and historical transformation in Marakwet from both these angles, in some instances approaching the biographies of people via a focus on certain types or uses of pot and in others exploring the biographies of different kinds of pot by drawing on the recollections and memories of various individuals involved in their production, use or exchange.

Our intention in doing so is partly to demonstrate the significant potential that might be mined from an object-centred approach to the recent past in Africa. Exploring broader social and political institutions via the embodied practices and material interactions that constitute them grants access to personal and quotidian narratives of change that are situated within and related to shifting local landscapes and political economies as much as they are to broader nationally- and globallyrooted historical constructs. In this sense, the account of recent Marakwet history we outline in this article will, we hope, contribute to the growing corpus of historical and 
anthropological works that focus in on dynamic local-level negotiations of change emanating from global processes. ${ }^{12}$ Underlying our discussion is a characterisation of resilience as a feature of daily life that is rooted in, and articulated by means of, the particular dynamics of change over the long term rather than any kind of stasis or equilibrium. We conclude by suggesting that this sense of resilience endures in the contemporary world.

\section{Research area and methods}

The Marakwet are members of the Kalenjin group of southern Nilotic speakers and occupy a roughly $40 \mathrm{~km}$ stretch of the Elgeyo escarpment in the western Kerio Valley, from Arror in the south to Chesegon in the north (Figure 1) as well as significant portions of the adjacent highlands. Their intensive irrigation agriculture system, ${ }^{13}$ which harnesses water from rivers and streams and directs it into furrows that flow down the escarpment into field systems on the valley floor, has been in place since long before the colonial era, with archaeological and oral-historical data pointing to a time-depth of roughly 300 years. ${ }^{14}$ Prior to the colonial era the Marakwet population were not a single ethno-linguistic group, but rather comprised several distinct communities, each with their own sub-divisions. As in previous work, we here focus on Sibou Village in the north of the region and the adjacent trading centre of Tot.

All of the research undertaken for this article was conducted amongst the Marakwet community in Sibou. A survey and concomitant collection of interviews and household object inventories was carried out in 2012 by SD and HC in order to be integrated with Moore's extensive inventories collected several decades earlier, and Alice Welbourne's doctoral research, which paid great attention to pottery. ${ }^{15}$ The data that emerged from this research were then developed through various in-depth conversations and group discussions over several visits to the region between 2012 and 2014 and further fieldwork was then undertaken in 2015. This latter phase involved a series of focused interviews convened by SD and HC with ex-potters and members of the community who had extensive knowledge related to pottery. 


\section{Mun collecting and reciprocal exchange}

The Endo ceramic assemblage has historically encompassed a wide variety of vessel forms, each attached to specific functions (and in some cases multiple functions). Figure 2 illustrates some of the most common vessels, and their respective uses: Kire, kitebar, terepar, kapepka, kipsagat, kossum, terre ma' and morr bo terr. Prior to the availability of aluminium sufurias (which we discuss further on) cooking was divided between four pots - kire, kitebar, terepar and kapepka - and despite the widespread use of sufurias today, most households have retained and continue to use at least one of these vessel types. Various medicines are still commonly prepared using either kipsagat or kire, and many households store water in large handle-less vessels called kossum. Terre ma' and morr bo terr are two large alcohol brewing vessels, once in regular use throughout Sibou, that have become extremely uncommon in the last few decades (again, we discuss this further on). Throughout recent history all of these pot types were produced and traded by women, with the exception of terre ma' and morr bo terr, which were made collectively due to their size, and often involved male labour. ${ }^{16}$ Whilst there are several elderly potters still alive in Sibou, none remain active, and today when new pots are required they are either purchased in masop (the highlands) where there are still active potters, or at external markets (most commonly Lomut, in West Pokot, and Eldoret).

It is clear from discussions with ex-potters currently in residence at Sibou that, when it occurred locally, pottery manufacture was never a strictly hereditary occupation. Novices learned and perfected their craft via mentoring relationships with older more experienced potters, and whilst these relationships were on occasion initially formed between mothers and daughters, they were more commonly established over longer time spans between experienced potters and their daughtersin-law or other younger women who had married into the clan. This arrangement makes sense when one considers the central role and significance attributed to secrets in the world of pottery (and indeed in Marakwet society more broadly). Pottery production in particular involved women's secrets - especially those relating to fertility and childbirth. It was, and remains, highly uncommon for women potters to transfer such secrets to women outside their clan (women become a member of a clan on marrying in). 
All of those interviewed recalled a reciprocal exchange system that was in place for most of the $20^{\text {th }}$ century. This system terminated roughly 20 years ago primarily as a result of bouts of violence that recurred between the Marakwet and neighbouring Pokot communities between 1990 and 2001. In situations requiring rapid flight, pots are cumbersome and heavy objects to transport with the likelihood of breakage far outweighing that of successful relocation. Such conditions also made it impossible for the ritual site of Chemet, which we discuss below, to be maintained appropriately. The firing of large pots, which took place at Chemet, required a large, organised labour force to cooperate over long periods of time - peace and security were prerequisites.

Nevertheless, when it was still in place this system involved potters working close to their homes with mun (clay) that had been collected from locations high up on the escarpment by local clients in part-payment for a pre-arranged number of pots. After producing a batch, potters would relinquish the required vessels to their clients and remain with several for their own use. These were either added to the potter's own domestic assemblage, traded with neighbours, or (most commonly) exchanged at nearby markets in Tot, Chesegon, or Kolowa. Ko-Chelimo, a woman of the Kasengen age-set (initiated between 1930 and 1946), ${ }^{17}$ regularly undertook mun-collecting journeys for local potters in her pre-marital years, she recalled this system as follows:

"In the past if someone wanted a pot... that person would find others who also needed pots, they would assemble and climb up above Sibou together. They would travel to find mun at three particular places to bring... [back down to Sibou]. Near Chemet was the source of red mun, at Kapkitany in Kaseman was the source of a darker mun - but not black... and at Semwol, on the Embubut, was the mun called ngoyon, which is totally black in colour. This place is very far away. It was always necessary to collect mun at all three places... in order for pots to be strong. You must wake very early, you must all go out and no one would return until late at night. After going through that trouble of collecting each different material... they were given to potters at Sibou, who were known throughout the village. This was the process I experienced when I was young... it continued this way until the time I was married". 18 
Like many other interviewees, Ko-chelimo places great emphasis on the importance of mun in producing strong and durable Marakwet pots and specifies the requirement for mixing all three different kinds of mun together. Indeed, this process was of such great importance that it necessitated long and arduous days of travelling between the three different sources at Chemet, Kapkitany, and Semwol, with clients often not being able to return home 'until late at night'. It is important to point out that the significance of mixing these different clays together to produce strong pots was not purely practical. Clay is an integral component of all rituals in Marakwet, and the mixture of different kinds of clay is deeply symbolic ${ }^{19}$. In this sense, the special ritual and symbolic values that are located in various pots more generally can be seen as manifestations of the fundamentally inextricable nature of materiality and meaning.

During other interviews it was also pointed out that the locations of the three mun sources regularly underwent ritual purification ceremonies, during which community elders would slaughter small livestock and leave offerings of kipketin (honey beer) to ensure the continued provision of high quality mun and 'to make sure pots continue to bring blessings' ${ }^{20}$ Such blessings were brought via the ritual connections that exist between clay, circumcision, fertility and food. It is perhaps significant here to consider how forging any item out of a 'raw' material tends to invoke ideas of fertility as making, a cracked pot in many parts of the world being likened explicitly or inexplicitly to a failed womb. ${ }^{21}$ The dome-like kiln used for firing pots was definitely envisaged as a womb in Marakwet, ${ }^{22}$ and it was this that necessitated the many rituals and offerings of kipketin - a substance always used to bless unions or indeed any activity associated with fertility (i.e. marriage, circumcision and harvest). Pots were thus used to literally and symbolically produce community well-being through food, water, kipketin and blessings.

The fact that the mun sources were located high up on the escarpment above Sibou was clearly very significant - their remoteness held great influence over the reciprocal exchange system that existed between potters and the wider community. However, remoteness, in this context, was also a question of secrecy and separation in relation to knowledge. During the time when the reciprocal exchange system was in operation, the most secret rituals of the Marakwet were always held high up in lagam. Being remote was a guarantee of the potency of knowledge. The long journeys that 
were, by necessity, undertaken to each different source served as integral components in an intricate and geographically expansive chaîne opératoire. ${ }^{23}$ It was the effort inherent in these journeys that was exchanged for the labour of the potters, and subsequently recompensed with the provision of pots. Potters were in turn rewarded for their labour by trading the remaining vessels at nearby markets on the valley floor for a range of items, including foodstuffs, animals and ritual objects. In this way, the exchange system was recursively entangled in a network of regular movements up and down the escarpment, which connected key locations in the landscape above Sibou with both the wider Marakwet community and members of external groups who frequented the markets at Tot and Chesegon.

\section{Chemet cave, regional trade and the emergence of Tot centre}

Whilst the practice of retrieving mun from sources high above Sibou in exchange for the labour of potters was undoubtedly longstanding, it was by no means always the dominant system of production; moreover, its entanglement with the markets at the foot of the escarpment, where potters regularly exchanged their remaining pots, did not solidify until the middle years of the $20^{\text {th }}$ century (the 1940s-1960s). It was not until this time that the settlement of Tot emerged as an administrative centre and tax collection point subsequent to the construction of the road that meanders along the valley floor. The colonial government instigated the construction of this road in 1913 and it was completed in $1936 .{ }^{24}$ A path had existed in pre-colonial times, which had already constituted a key trade route, a fact substantiated by its Marakwet name aarap koton, which means 'road of succour'. ${ }^{25}$ However, the new road was a substantial improvement and, particularly through its facilitation of motor vehicle transportation (at least for some months of the year), served in some way to connect various Marakwet communities to an expanding national infrastructure, whilst concomitantly supporting the very gradual influx of a range of new items from further afield. Writing in 1973, Kipkorir pointed out that "Junior members of the present Korongoro set are known as Kakipanga, since they were initiated during the late 1930s when the machete (Swahili, panga) was brought into use". ${ }^{26}$

Many interviewees also pointed out that prior to this time pots had been traded far more frequently at an entirely different location. Several ex-potters, and relatives 
of now-deceased potters, recalled stories and memories of an early $20^{\text {th }}$ century production and market site high up on the escarpment. Discussions centred on a large cave located close to the source of red mun at Chemet, which had been utilised by potters who lived and worked above Sibou, and who did not depend on reciprocal exchange (because of their proximity to the sources of mun). This cave, shown in Figure 3, was frequented both by members of the local community and by members of external groups who came from various distant locations to trade their own local produce for Marakwet pots; ${ }^{27}$ in serving this purpose it operated as an important nodal point in a wide-ranging regional exchange network.

Whilst many interviewees recalled that pots had been traded at markets at the foot of the escarpment alongside this trade at Chemet (before the emergence of the administrative centres), they also pointed out that these exchanges were far less frequent, and that the valley floor exchanges were significantly less central to regional trade than they eventually became when the trading centres emerged and commerce intensified. This makes sense when one considers the historical significance of settlement movement up and down the escarpment by the Marakwet. Today, Chemet seems high up above the settlement of Sibou, but in the past there was substantial settlement above it, and its position was thus more central than it now appears. Kipchemuny, who is of the Kipnyikeu age-set (initiated in 1975) and whose mother had regularly worked as a potter at Chemet, recalled the situation as follows:

"Chemet cave was like a shop... this was before Tot and Chesegon market were started... in the 1920s and 30s. Before the markets the cave where most pots were sold was Chemet. It was a very big cave. It was near to the source of red coloured mun... Close to Chemet were potters from Kacheshaban... at Kapkitany were potters from Kaptobogo, at Semwol were potters from Kaptul... People came from far around to buy pots at Chemet including Turkana and Pokot from Baringo and from Cherengani". ${ }^{28}$

It has been well documented that Marakwet communities have a long history of interaction with various neighbouring groups. ${ }^{29}$ It is therefore unsurprising to hear of exchange relationships between Marakwet potters and individuals from West Pokot (to the north west), Turkana (to the north), and Baringo (to the east), that were already 
well established by the early decades of the $20^{\text {th }}$ century. Indeed, the existence of wide-ranging regional trade networks that, throughout history, have bisected economic and ethnic boundaries, and linked various diverse communities, has been widely documented across eastern Africa. ${ }^{30}$ Accounts of Chemet cave's prominence prior to, during, and after the emergence of the administrative centres on the valley floor support the suggestion that for Marakwet communities these interactions were equally extensive in the deeper past. ${ }^{31}$ These accounts also lend credence to the argument that when administrative centres did emerge along the valley floor they served more to re-configure and re-articulate already existing trade relationships than they did to drastically transform the nature of exchange altogether.

Sibou pots were clearly very important and widely sought-after items in a web of shifting regionally specific commodities long before any considerable infrastructural development occurred in the western Kerio Valley. As yet it is uncertain precisely how dispersed the various other locations in this trade were and therefore difficult to determine the degree to which the trade was orientated along the path at the foot of the escarpment prior to the emergence of the administrative centres. The research undertaken for this paper suggests that exchanges took place at sites across the escarpment and further out in the Kerio Valley as much as they did along the escarpment base. In any case, it seems clear that there was a gradual reorientation of focus from wherever the agglomeration of exchange relationships within this trade network had initially formed to Tot, Chesegon, Kolowa and other centres along the valley floor, when trade began to converge upon them in the late 1940s and 1950s. This was certainly the process recalled by those with knowledge and experience of Chemet cave. Indeed, Kipchemuny's account continues:

\footnotetext{
"Before independence Tot and Chesegon were very popular... when the markets were growing, it was the case that those [potters] who already lived down in Sibou saw the demand for pots [to be sold there]. These were the ones who would organise people to climb up the escarpment to collect mun. They made pots either up there or in Sibou, and they sold the ones that were left at [Tot and Chesegon] market. They could also cooperate with family members... mothers, who still lived up there. For some time selling at Chemet cave was divided, there were still some people who
} 
would come and buy at the cave... it depended on their route. Also, terre ma' would have to be sold at the cave as they were too big to be brought to market". ${ }^{32}$

As Kipchemuny points out, potters who lived in Sibou and worked with clay that was collected in exchange for their finished pots were instrumental during this period of adjustment. Their reciprocal exchange system was harnessed to facilitate the flow of pots away from Chemet and into the newly prominent markets and came to operate as a vital link connecting the distant sources of mun with the new administrative centres. From the late 1940s this longstanding exchange system offered a framework for Sibou potters to engage actively with and capitalise on the transformation of the Marakwet region, and indeed throughout this period there was a general settlement gravitation toward the lower reaches of the escarpment in order to facilitate the exploitation of new opportunities on the valley floor. ${ }^{33}$ This perhaps exemplifies a side to Kenya's early economic development that is rarely addressed in contemporary research. Kenya's early economic development and the connected improvement and expansion of its national infrastructure are regularly discussed in terms of their conjoined function as a mechanism for the exertion of colonial power and dominance in various rural contexts, particularly through the extraction of taxes. ${ }^{34}$ Such emphases, although undoubtedly pertinent in many respects, perhaps also work to exclude more nuanced understandings of these transformations by means of their position within locally constituted historical processes.

\section{Pre-colonial 'localised reciprocal exchanges' are often implicitly} conceptualised as simplistic and assumed to stand apart from the abrupt imposition of monetised transactions and integration into wider formal markets. In reality precolonial exchanges seem to have been regionally extensive and highly formalised with well-established patterns of movement and key locales or nodal points. Colonial infrastructure and monetisation did not so much replace and 'modernise' these deeper practices, but rather came to be part-configured around them, with local actors reshaping both their own actions and the nature of the emerging colonial economy. Indeed, as we have recently explored with regard to contemporary market practices and female exchange relations, the 'market' and 'non-market' do not stand as separate spheres of economic activity, nor as 'contemporary/modern' vs. 'past/traditional' activities, but rather as inseparable components of dynamically negotiated household 
economies (which also incorporate ritual activities and thus comprise strong links to the wider political economy of clan identities and so on) that resonate across the spatial and temporal landscape of the Marakwet. ${ }^{35}$

Certainly, in the case of the Sibou potters, the regional transformations associated with the emergence of Tot and other colonial-era centres were actively absorbed into an existing set of daily practices and skills. Those who exploited the burgeoning popularity of the new markets did so by means of the "currents of the lifeworld", to quote Ingold, ${ }^{36}$ in which pots were inextricably entangled, i.e. the materials, individuals, and relationships involved in their construction and exchange. In this sense, whilst the development of these new centres and their entanglement with the wider Kenyan state clearly reflected fairly significant material and social transformations in the everyday lives of many in the Sibou community (as was the case elsewhere in Kenya at this time), change did not solely (or even predominantly) flow from the 'outside' in. As we explore further in the example below, it would seem more appropriate to consider it as occurring at the nexus between the newly emerging colonial regime and enduring modes of dwelling in and interacting with the Marakwet landscape, as encompassed by various grounded livelihood practices.

\section{Chief Chemutut, tum nyohoe and the terre ma' as a communicative device}

Some of the most important vessels produced at Chemet cave were large alcohol containing vessels called terre ma' (Figure 4). These pots were much larger than all the others in the Endo assemblage and required such vast quantities of mun that they could not be produced far from the three sources high up on the escarpment. Many informants recalled the vital role terre ma' pots had played in the ritual period of tum nyohoe, the last in a series of ceremonies which together symbolised marriage. Tum nyohoe, literally meaning 'full ceremony', has historically taken place fairly late in a married couple's life (after at least three children have been born from the union) and constitutes a significant transition into elderhood. This is particularly the case for men who, after tum nyohoe, may take on a more dominant social standing by means of their involvement in the organisation and leadership of other important ceremonies. ${ }^{37}$ 
Historically, terre ma' pots performed several different symbolic roles throughout tum nyohoe, which revolved around their containment of alcohol. Following her doctoral research, Alice Welbourn argued that the most significant of these was their central function in the meeting of the elders from the man's kor (village) towards the end of the ceremony. ${ }^{38}$ Welbourn recounted that this meeting, the second part of which took place out of auditory range and could only be attended by the man undergoing tum nyohoe and other men whose eldest sons had already undergone the ceremony, involved the passing down of esoteric knowledge or 'secrets'. She also posited that during this meeting the terre ma' was correlated with the sun (asis), arguing that the select individuals who conferred secrets were referred to either as berrer bo terr 'the rainbow of the pot' or berrer bo asis 'the rainbow of the sun'. She summarises her interpretation of the significance of the terre ma' during this meeting (and the wider ceremony) as follows: "In one pot therefore is presented and represented the male universe of patrilocal residence, animal husbandry, irrigation maintenance, the social importance and allegiance of the kor and the access to power which kipketin bears". ${ }^{39}$

Whilst the terr ma' was undoubtedly of great importance during tum nyohoe, more recent research has suggested that it was never correlated with asis (in the sense of its meaning as 'sun'). Moreover, the notion that it represented the 'male universe of patrilocal residence' is rather a restrictive interpretation that fails to account for the fact that it performed numerous different roles and comprised numerous different meanings simultaneously, like the broader tum ceremony itself. Undoubtedly, the terre ma' would have reflected on clan identities and male roles in production and reproduction, but it is important to remember that by the time of the meeting to confer secrets between men it would have already bestowed its blessings upon the ceremony and the clan via the preceding days of dancing. Indeed, its main function throughout the ceremony was the communal drinking of sorghum beer (and later maize beer) through maize stem straws and by means of tins, and the tum nyohoe ceremony as a whole was more a celebration of the fecundity of women than it was an enactment of the power of the male universe.

Nevertheless, terre ma's position in this important ceremony also predicated its use in a wide range of other ceremonies executed at various locations across the 
escarpment, most of which related to the fundamental themes of fertility and death. Its centrality to these other ceremonies imbued it with powerful symbolism and it served to legitimise the various life-stages and processes over which it physically presided, or as Kochebet Chemutut put it, it made them 'real':

\footnotetext{
"Of course, there are many important roles that it [terre $m a$ '] plays... but it also is a sign. It stays standing for four days during tum, the people watch it and look after it, they make sure it does not fall down. The elders sit together and look after the terre $m a^{\prime} . .$. It is a marker that the ceremony is going on. Without it, it is like the ceremony is not real". ${ }^{40}$
}

The indispensability of these pots to the ritual life of the community, and their ability not only to make ceremonies 'real' but also to embody their social potential, meant that they were extremely valuable assets to the few who acted as custodians of them and who, as a general precedent, were highly regarded and influential members of society. It is widely remembered today that only three individuals from the Sibou community owned them in the recent past: a public roads officer called Kimuko, a prominent elder and leader called Poseo, and a chief called Paul Chemutut. ${ }^{41}$

Although Chief Chemutut is now deceased, it became clear during discussions with his youngest wife, Ko-chebet Chemutut, that his ownership of two terre ma' pots was integral to his administration of a geographically vast and socially diverse zone. Chemetut's position, which he occupied from the early 1940s until the 1980s, was one of the earliest created by the colonial government in Marakwet, and his administrative range vastly exceeded what would later become the standard for subsequent chiefs in the Marakwet region (and across post-colonial Kenya in general). The area he oversaw, which roughly encompassed what is now Tot division, would later be divided into five locations and twenty-five sub-locations, administered by several chiefs and assistant chiefs respectively. ${ }^{42}$ In managing this expansive area, Chemutut took advantage of the demand for his ceremonial pots at events occurring in the villages and clans surrounding him. His provision of the mandatory vessels, which were carried up and down the escarpment by young men (as per a long-established practice), played a significant role in enabling him to maintain his high standing throughout several disparate communities. Moreover, in doing so he was directly 
associated with the most senior elders and, at least to some degree, implicated in their ritual paramountcy. This system also served as an ingenious means of ascertaining upto-date news and information that would otherwise not have reached Chemutut's post, which was relayed to him when the pots were returned. Ko-chebet Chemutut explained as follows:

"His [chief Chemutut's] terre ma' pots were very important for [his] being chief... People would come from very far to take them and use them. His area was so big that you could not walk across it in one day... The pots allowed him to know where all the ceremonies were taking place. If he wanted, he could go to those places to give out information, and talk to the elders. Even if he did not go to the ceremony he would be brought a Loh [gourd] of honey beer as a gift, and the news from that place would be told to him". ${ }^{43}$

Clearly, the power of terre ma' pots was not restricted to their central roles within various ceremonies but also, by means of their repeated use at numerous important events over substantial periods of time, they were able to perform a much broader communicative function. In harnessing their innate propensity to act as axes of expansive and regular information exchanges, Chief Chemutut used these pots to negotiate the early decades of his administrative position. It is, of course, important not to disregard the many other strategies and processes by means of which Chief Chemutut negotiated and performed his office throughout his tenure, many of which had nothing to do with alcohol pots. We do not have space to discuss these other dimensions of Chief Chemutut's influence on Marakwet political history here, but it is important to note that our argument is not that the terre ma' constituted Chemutut's only, or indeed primary, approach to his new position, but rather that it was of great significance within a broader ensemble of methods. With its connections to the management of fertility, marriage, animals and land, it provided the material and symbolic means that allowed for the performance of community well-being that was invested in the adult men who made up the kokwo (council). Chemutut, who was part of this kokwo group, used his pots to consolidate a newer role as primus inter pares as a created colonial chief, and legitimised his new role through that means. He could never have ruled as a colonial chief by fiat - he would always have needed the consent of other adult men. Thus, Chemutut implemented ceremonial alcohol pots, 
and the customs and traditions in which they were implicated, as political devices to articulate his new authority during the colonial era. His pots elided several potentialities, his chiefly power becoming something that was connected to the blessings of the kokwo and the ancestors.

Chemutut's position was a combination of the colonial office of chief and also his standing as an elder. Rather than causing a rupture to daily ritual activities, and by extension the general organisation of Marakwet society, his colonial post came to depend upon them. Moreover, his direct material facilitation of these various ceremonies imbued his post with high significance rather than irrelevance. In this sense, Chemutut's chiefship precipitated a reshaping of pre-existing local political systems in relation to their de facto engagement with, and enmeshment within, the new national political order, rather than their decline or their disconnected parallel continuation. This process of political transformation took place at roughly the same time as the re-orientation of regional trade that occurred when the administrative centres emerged along the foot of the escarpment. In both instances the Marakwet social world was not static or passive, but rather open ended and dynamic, behaving as a malleable framework that provided its constituent human and material components with the means to perform in new contexts as and when they arose. Pottery was significant across a range of social contexts, from domestic use to the transformation of the political economy of Marakwet life, and individual pots themselves encompassed multiple potentialities across these different contexts.

\section{Plastic drums, sufurias and the decline of pottery production in Sibou}

Throughout the final years of the colonial era and into the decades that followed Kenya's independence (1963) the trading centres in the area surrounding Sibou (and across the western edge of the Kerio Valley in general) continued to solidify into their prominent regional positions, and their respective market places remained integral locations in local exchange systems. These centres also increasingly facilitated the influx of various mass-produced commodities from larger settlements close by. By the 1970s Tot, Chesegon, and Chesengoch had, to a certain extent, been incorporated into a road network that connected them to Iten/Tambach and Kapenguria, which were the capitals of Elgeyo-Marakwet District and West Pokot District respectively 
(counties since 2013). ${ }^{44}$ Having said this, there was still very little traffic along the foot of the escarpment, with the road being impassable for most vehicles for a large portion of the year and vehicles arriving in Tot on average only once a month to provision the store well into the 1980s. Nevertheless, the movement of commodities and people gradually intensified between these locations, alongside the enduring trade in local produce. The valley floor centres were increasingly interwoven with, and became representative of, broader economic changes in Elgeyo-Marakwet District. ${ }^{45}$

Between 1990 and 2001 the Kerio Valley experienced recurring bouts of severe violence. Politically-charged armed conflict between the Marakwet and neighbouring Pokot groups saw the displacement of thousands of Marakwet families and hundreds of deaths. ${ }^{46}$ It was in this context of unrest and uncertainty that pots eventually stopped being produced in Sibou. Many of those interviewed in 2015 recalled producing pots regularly throughout the first half of the Chebterntur initiation period (1975-1989), and indeed Moore's doctoral research noted regular pottery production and use during this period. However, household object inventories collected during this time also show that sufurias were found in all households surveyed. ${ }^{47}$ The close familiarity with sufurias that had emerged from Marakwet's gradual post-independence infrastructural and economic development in the years preceding the 1990-2001 violence thus led to their increasingly ubiquitous utilisation when the practice of pottery production became untenable due to insecurity. On top of the incorporation of sufuria vessels into domestic cooking pot assemblages, plastic drums and containers came to be used in place of alcohol-brewing pots.

Importantly, almost all of those interviewed in 2015 attributed this decline in the demand for pots not solely to the limitations imposed by conflict but rather to the increased availability of various new materials and commodities that were able to fulfil previously niche functions. Ko-chebor, a potter who produced her last batch of pots during the Chebterntur initiation period, explained as follows:

"The sufuria was why we stopped making pots. People decided to use sufurias because they require less firewood... they cook food quicker [than pots]. Also, sufurias became available at the same time as ... other foods that had not been here 
before... rice, tea, cooking oil... [these] are better to be cooked in sufurias than pots". 48

What is most significant about Ko-chebor's description of the decline of pottery production in Sibou is its decidedly pragmatic timbre. Many others interviewed in 2015 also did not associate the infiltration of plastic containers and aluminium vessels into activities that had previously solely been performed by pots with a sense of loss or nostalgia. Instead, this process was repeatedly characterised as a fairly straightforward development in a long history of adaptive and dynamic socio-material transformation. Discussions rarely assimilated with the notion of causality and the influence of new materials as a driving force in the disintegration of previously common practices. They instead tended to involve considerations of the decisions made by those who first adopted them, and the rationale behind those decisions. In other words, the expansion and development of nearby trading centres was not interpreted as a pressure that exerted change at a household level on its own terms. It was rather envisaged as a source from which people drew various new materials that were in turn integrated with, and used to reshape, a range of local activities in relation to new socio-political constraints and possibilities.

One such constraint was the 1990-2001 conflict mentioned above, but another was the spread of Christianity, which came to take hold in Sibou during the 1980s following the installation of a permanent Catholic mission in the mid 1970s. ${ }^{49}$ Along with this new religion came a ban on beer and an increasingly widespread recognition of church weddings as a replacement of tum. Christianity demanded a different kind of subject to that which had been required before, an adherent with different horizons and aspirations. It encompassed the wearing of new forms of clothing and the placing of value on formal education above other social rewards and forms of knowledge attainment. It also nurtured different ideas about marriage and the relationship between household and clan. Ko-chebor points out that sufurias were better for cooking new kinds of foodstuffs; they did not simply replace pots but were rather implicated in the emergence of entirely new consumption patterns. The new forms of container that proliferated came to comprise new forms of social status, many of which were not related to kipketin and its ritual power whatsoever. 
In this respect, exploring the changes that came about within domestic material culture assemblages during the 1980s and 1990s, and in-particular within the world of Marakwet pottery — perhaps the most domestic of items - unveils how this sphere was inextricably entangled with broader processes of transformation in the political economy of Marakwet. New materials and forms encompassed new subjectivities and their performance in daily life, but most households retained clay pots alongside these new objects - assemblages were re-organised and adjusted as part of a broader-scale adjustment of social institutions and value systems that was taking place at the time (see Figure 5). The decline of pottery production in Sibou occurred at a time of great political uncertainty and unrest, following far-reaching religious transformations that had begun to take hold in the preceding decade. However, to those who experienced it, this process did not reflect unmitigated and intractable disjuncture but rather the seizure of new socio-material opportunities, the pursuit of new aspirations, and their incorporation into community life.

The clearest encapsulation of this is perhaps the case of the terre ma', which was one of the earliest vessels to stop being produced in Sibou. Whilst terre ma' pots are still sometimes used in Sibou, in many contexts large plastic drums have come to be used in their place. These can be purchased relatively cheaply and moved across the escarpment to different locations with ease and little danger of breakage. This situation contrasts starkly with how things were previously, when a terre ma' could take up to three weeks to construct using a large work force and could only be moved across the escarpment with great difficulty and risk. The profoundly dissimilar architecture and physiognomy of the now ubiquitous plastic drums has unquestionably led to differences in the way different forms of alcohol are contained, transported, and consumed in Sibou. Perhaps most notably, the new containers are far more common, and generally not considered to be capable of exerting the same ritual power as a terre ma' self-evidently or axiomatically. However, despite these differences they are still able to act as, and take on the power of, the terre ma' during certain ceremonies, where they continue to serve a key symbolic role. Silas Kibor explains this as follows:

"These days the terre $m a$ ' has been replaced by plastic drums... large plastic drums are used in tum, they are used at any time a terre $m a$ ' would [have previously been] 
used. These drums are treated like a terre $m a^{\prime} . .$. they are treated with respect, it is like they have the same qualities of the terre $m a^{\prime}$... many are saying that the secrets of the terre ma' cannot be passed down through plastic drums, because many years ago [during the time of] the first terre $m a^{\prime}$.... those early people spoke words to it, and these words were not spoken to plastic drums. However they still treat these drums with respect during tum, they still act as though they are hearing secrets... [it is] not like before, but [successive] generations are still together in telling secrets". ${ }^{50}$

Kibor makes it very clear that the way plastic drums perform in the contemporary world is not the same as terre $m a^{\prime}$. In this sense it would be inaccurate to consider them as being assimilated all-inclusively into a pre-existing category. Secrets are passed down today whether a terre $m a$ ' is present or not, but the inability of plastic drums to fulfil the roles played by terre ma' (symbolising secrets and making them performative) means that people's behaviour toward them is not the same as their behaviour toward terre $\mathrm{ma}^{\prime}$. Rather than reinforcing or preserving the prior order, plastic drums have actively generated a new context, within which they have become entangled in new values and institutions. Thomas explained this biformity that everyday quotidian objects are able to encompass using the case of tiputa - poncho-like garments which replaced barkcloth wraps across Polynesia in the $19^{\text {th }}$ and $20^{\text {th }}$ centuries. ${ }^{51} \mathrm{He}$ argues that 'the value of tiputa ... inhered in their doubleness; they were things that mobilized certain precedents, certain prior values that cloth possessed, on the one hand, but possessed novelty and distinctiveness on the other'. In precisely the same way, plastic drums in Sibou have come to evoke the influence and vitality of the terre ma' without explicitly being it, they represent novelty and tradition in equal part, serving to recast prior values by means of the modern context that they concurrently exemplify. ${ }^{52}$

\section{Conclusions}

This article has explored Marakwet history via the specific theme of pottery, yet in doing so it has not remained circumscribed by any one particular sphere or scale of analysis. Our discussion has crossed from the domestic context to the ritual, and from local reciprocal exchange systems to largescale political and economic transformation. This has been possible not only because individual pots - the loci of 
our analysis - move actively between different contexts in Marakwet (although this is the case), but also because the meanings that they invoke via their implication in various different daily activities also have the ability to refer across both time and space to other meanings invoked in other contexts. In other words, pots may well have social lives, but this article has been more concerned with their role as embodiments of social potential, and the ways in which physically and temporally distant practices remain imminent in the activities undertaken with them (or with potlike objects), taking part in the crafting of new contexts for social action and the performance of new subjectivities.

It is clear from the narratives explored in this article that the ritual and the domestic are not spheres that can be simplistically separated in Marakwet. Each of these realms are engaged with by means of practices and institutions that, at any given moment, reach across and recursively imply numerous different private and public experiences. The blessings that are bestowed by pots placed on the roofs of houses are at least in part contingent on the ritual uses of pots in other contexts across the Marakwet escarpment, past and present. Equally, where sufurias have taken the place of clay pots on thatched roofs (performing a practice that had previously been exclusive to clay pots) they invoke the blessings of pots regardless of their inability to fully bestow them. Furthermore, neither ritual nor domestic contexts of pot use have ever been separable from broader-scale transformations in the political economy of Markwet. The world of pottery has been a grounds for the articulation of processes ranging from broad-scale infrastructural and economic transformation to the emergence of Christianity in the 1970s-1980s, and from the establishment of new administrative offices and powers during the colonial period to the outbreak of fierce inter-ethnic violence in the 1990s.

The world of Marakwet pottery has comprised a realm where the past serves to make sense of and organise the possibilities and constraints that emerge in the contemporary world. Despite the eventual disappearance of pottery production in Sibou, we would argue that this resilient open-endedness has not diminished in recent years. Not only do certain forms of pot continue to be used in the present day alongside newer materials, but histories of pottery production, use and exchange continue to inform the use and experience of these materials, sometimes in surprising 
ways. The examples we have explored attest to a dynamic process of cultural reproduction that is founded on the ability to embed continuity within change (and vice-versa), an ability that can be ascertained via explorations of agricultural and exchange practices as much as it can through a concentration on a particular material culture category. As we have argued elsewhere, cultural change is rarely enacted or experienced as externally-driven rupture in Marakwet. Instead, it is often a creative and improvised temporally-contextual act, constitutive of a form of resilience that goes some way to explaining the enduring successes of this small rural community.

\section{Acknowledgements}

We primarily wish to thank the community at Tot-Sibou for their patience and insight during the fieldwork undertaken for this article, and the Institute for Global Prosperity's Marakwet research team led by Timothy Kipkeu Kipruto, with special thanks to William Chukor, Nelson Bailengo, Noah Kiplagat Ruto and Sammy Kimwole. We would also like to thank Acacia Leakey for producing the illustrations used in Figure 2, and Dan Hicks and Peter Mitchell for reading and commenting on numerous drafts. Furthermore, we wish to thank the Kenyan National Commission for Science, Technology and Innovation (NACOSTI) for research permission and the National Museums of Kenya for support and affiliation. We would like to thank the Clarendon Fund, the Leverhulme Trust, the McDonald Institute for Archaeological Research, University of Cambridge and the British Institute in Eastern Africa for financial and logistical support.

\section{Notes}

1. Moore, Men, Women and, and Space, Text, 146-150.

2. Welbourn, Endo Knowledge, 97.

3. See also Davies and Moore, "Landscape, time"; Davies et al., "Revisiting the"; Moore, Space, Text.

4. See Moore, Space, Text, 98-161.

5. Appadurai, The Social Life; Kopytoff "The cultural biography". 
6. As critiqued by Moore, Still Life, 5; cf. Luvaas, "Designer vandalism"; Castells, The Rise of .

7. See Appadurai, The Social Life; Hodder, Symbols in Action; Miller, Stuff; Moore, Space, Text; Schiffer, The Portable Radio; Thomas, "The case of"; Holtorf, "Notes on the".

8. Miller, Materiality, 10.

9. Gosden and Marshall, "The cultural biography"; Gosden and Knowles, Collecting Colonialism.

10. Kopytoff, "The cultural biography".

11. Hoskins, "Agency, biography”, 74.

12. For example, Moore, Still Life; Wilmsen, Land Filled; Ortner, "Patterns of"; Wolf, Europe and the; Catley et al., Pastoralism and Development; Galaty, "The indigenisation".

13. Davies et al., "Revisiting the".

14. Davies and Moore, "Landscape, time".

15. Welbourn, Endo Knowledge; Moore, Men, Women and.

16. Welbourn, Endo Knowledge.

17. The Marakwet age-set cycle consists of eight age-sets (ibinwa or eben). See Kipkorir, The Marakwet; Moore, Space, Text, 60.

18. Interview with Ko-chelimo Kachume, 19/06/2015.

19. Different clays were needed to make high quality pots, but the mixing of red clay with black was also ritually significant. Red clay is marked on bodies as a significant part of the transferal of secrets during circumcision, and when initiates of both sexes come out through kibuno they are smeared in red clay. It is the colour of fertility, life and childbirth.

20. Interview with Ko-chebor, 20/06/15.

21. See Saidi, "NAKABUMBA"; Spindel, "Potters and pots"; Feldman-Savelsberg, Plundered Kitchens.

22. Although not all pots were made in kilns, many were fired out in the open.

23. See Sellet, "Chaine operatoire".

24. Moore, Space, Text, 27.

25. Kipkorir, "Historical perspectives", 5.

26. Kipkorir, The Marakwet, 11. 
27. The Pokot most commonly sold milk and livestock, the Tugen honey and the Turkana salt.

28. Interview with Kipchemuny, 22/06/2015.

29. Kipkorir, "Historical perspectives"; Davies, "Some thoughts".

30. For example, Davies, "Economic specialisation"; Hodder, Symbols in; Anderson, "Agriculture and"; Spear, "Being 'Maasai"” and Mountain Farmers; Börjeson, "The history of".

31. See Östberg, "The expansion of"; Pollard et al., "Women, marketplaces".

32. Interview with Kipchemuny, 22/06/2015.

33. Movement to exploit new opportunities was not novel during this period. Indeed, it has been a key characteristic of Marakwet agricultural systems for centuries, see Davies and Moore, "Landscape, time".

34. See Van Zwanenberg, Colonial Capitalism; Berman, Control and Crisis; Tignor, Colonial Transformation.

35. Pollard et al., "Women, marketplaces", 415.

36. Ingold, "The temporality", 1.

37. See Kipkorir, The Marakwet, 52; Welbourn, Endo Knowledge.

38. Welbourn Endo Knowledge, 319-327.

39. Welbourn Endo Knowledge, 327. N.B. The terre ma' was not actually full of kipketin during tum nyohoe, it was full of either sorghum beer or in later years maize beer.

40. Interview with Ko-chebet Chemutut, 20/06/2015.

41. Interview with Silas Kibor, 20/06/2015.

42. Ministry of Planning and National Development, Marakwet District, 9. N.B.

There have been several boundary alterations since the 1990s, including those that

followed Kenya's adoption of a new constitution (in April 2010), which set in place the devolution of power from national to local governments.

43. Interview with Ko-chebet Chemutut, 20/06/2015.

44. Kurita, "A market on".

45. Republic of Kenya Ministry of Planning and National Development, National Development Plan, and Marakwet District Development Plan; Republic of Kenya, Marakwet District Development Plan; Moore, Space, Text.

46. Lynch, "Democratisation and"; Kenya Human Rights Commission, Raiding Democracy. 
47. Moore, Men, Women and, 220.

48. Interview with Ko-chebor, 20/06/2015.

49. Moore, Men, women and, 259.

50. Interview with Silas Kibor, 20/06/2015.

51. Thomas, "The case of the", 18.

\section{References}

Anderson, D. "Agriculture and irrigation technology at Lake Baringo in the nineteenth century". Azania: Archaeological Research in Africa 24, no. 1 (1989): 8497.

Appadurai, A., ed. The Social Life of Things: Commodities in Cultural Perspective. Cambridge: Cambridge University Press, 1986.

Berman, B. Control and Crisis in Colonial Kenya. London: James Currey, 1990.

Börjeson, L. "The history of Iraqw intensive agriculture, Tanzania". In Islands of Intensive Agriculture in East Africa, edited by M. Widgren and J.E.G. Sutton, 68-104. Oxford: James Currey, 2004.

Castells, M. The Rise of the Network Society. Oxford: Blackwell, 1996.

Catley, A., Lind, J. and Scoones, I., eds. Pastoralism and Development in Africa: Dynamic Change at the Margins. London: Routledge, 2013.

Davies, M.I.J. "Economic specialisation, resource variability and the origins of intensive agriculture in eastern Africa”. Rural Landscapes: Society, Environment, History 2, no. 1 (2015): 1-18.

Davies, M.I.J. “Some thoughts on a 'useable' African archaeology: settlement, population and intensive farming among the Pokot of northwest Kenya". African Archaeological Review 29, No. 4 (2012): 319-353. 
Davies, M.I.J., Kipruto, T., and H. L. Moore. "Revisiting the irrigated agricultural landscape of the Marakwet, Kenya: tracing local technology and knowledge over the recent past". Azania: Archaeological Research in Africa 49, no. 4 (2014): 486-523.

Davies, M.I.J. and H. L. Moore. "Landscape, time and cultural resilience: a brief history of agriculture in Pokot and Marakwet, Kenya”. Journal of Eastern African Studies 10, no. 1 (2016): 67-87.

Feldman-Savelsberg, P. Plundered Kitchens, Empty Wombs: Threatened Reproduction and Identity in the Cameroon Grassfields. Ann Arbor: University of Michigan Press, 1999.

Galaty, J. "The indigenisation of pastoral modernity: territoriality, mobility and poverty in Dryland Africa". In Pastoralism in Africa: Past Present and Future, edited by M. Bollig, M. Schnegg and H. Wotzka, 473-510. New York: Berghahn, 2013.

Gosden, C., and Y. Marshall. "The cultural biography of objects”. World Archaeology 31, no. 2 (1999): 169-178.

Gosden, C., and C. Knowles. Collecting Colonialism: Material Culture and Colonial Change. Oxford: Berg, 2001.

Hodder, I. Symbols in Action: Ethnoarchaeological Studies of Material Culture. Cambridge \& New York: Cambridge University Press, 1982.

Holtorf, C. "Notes on the life history of a pot sherd". Journal of Material Culture 7, no. 1 (2002): 49-71.

Hoskins, J. “Agency, biography and objects”. In Handbook of Material Culture, edited by C. Tilley, W. Keane, S. Küchler, M. Rowlands and P. Spyer, 74-84. London: Sage, 2006.

Ingold, T. "The temporality of the landscape". World Archaeology 25, no. 2 (2007): $152-174$. 
Kenya Human Rights Commission (KHRC). Raiding Democracy: the Slaughter of the Marakwet in Kerio Valley. Nairobi: KHRC, 2001.

Kipkorir, B. The Marakwet of Kenya: A Preliminary Study. Nairobi: East African Literature Bureau, 1973.

Kipkorir, B. Historical perspectives of development in the Kerio Valley. In Kerio Valley: Past, Present and Future, edited by B.E. Kipkorir, R.C. Soper and J.W. Ssennyonga, 1-11. Nairobi: Institute of African Studies, University of Nairobi, 1983.

Kipkorir, B. and J. Ssennyonga, eds. Socio-Cultural Profile of Elgeyo-Marakwet District. Nairobi: University of Nairobi Institute of African Studies, 1985.

Kopytoff, I. The cultural biography of things: commoditization as process. In The Social Life of Things: Commodities in Cultural Perspective, edited by A. Appadurai, 64-91. Cambridge: Cambridge University Press.

Kurita, K. "A market on the boundary: the economic activities of the Pokot and the Marakwet in Kenya". Nairobi Institute of African Studies, African Study Monographs 1 (1982): 71-103.

Luvaas, B. "Designer vandalism: Indonesian indie fashion and the cultural practice of cut 'n' paste”. Visual Anthropology Review 26, no1 (2010): 1-16.

Lynch, G. "Democratisation and 'criminal' violence in Kenya". In Democracy and Violence: Global Debates and Local Challenges, edited by J. Schwarzmantel and H. Kraetzschmar, 161-184. Oxford: Routledge, 2012.

Miller, D. Material Culture and Mass Consumption. Oxford: Blackwell, 1987.

Miller, D., ed. Materiality. Durham: Duke University Press, 2005.

Miller, D. Stuff. Cambridge: Polity Press, 2010 
Moore, H. Men, Women and the Organisation of Domestic Space Among the Marakwet of Kenya. PhD diss., University of Cambridge, 1983.

Moore, H.L. Space, Text and Gender: an Anthropological Study of the Marakwet of Kenya. Cambridge: Cambridge University press, 1986.

Moore, H.L. Still Life: Hopes, Desires, and Satisfactions. Cambridge: Polity, 2011.

Ortner, S. "Patterns of history: cultural schemas in the foundings of Sherpa religious institutions". In Culture Through Time: Anthropological Approaches, edited by E. Ohnuki-Tierney. Stanford: Stanford University Press, 1990.

Östberg, W. "The expansion of Marakwet hill-furrow irrigation in the Kerio Valley of Kenya". In Islands of Intensive Agriculture in East Africa, edited by M. Widgren and J.E.G. Sutton, 19-48. Oxford: James Currey, 2004.

Pollard, G., Davies, M., and H. Moore. "Women, marketplaces and exchange partners amongst the Marakwet of northwest Kenya". Journal of Eastern African Studies 9, no. 3 (2015): 412-439.

Republic of Kenya Ministry of Finance and Planning. Elgeyo-Marakwet District Development Plan, 1984-1988. Nairobi: Government Printer, 1985.

Republic of Kenya, Ministry of Planning and National Development. National Development Plan for the Period 1984-1988. Nairobi: Government Printer, 1984.

Republic of Kenya, Ministry of Planning and National Development. Marakwet District Development Plan 1989-1993. Nairobi: Government Printer, 1989.

Republic of Kenya, Office of the Vice-President and Ministry of Planning and National Development. Marakwet District Development Plan, 1997-2001. Nairobi: Government Printer, 1997. 
Saidi, C. "NAKABUMBA: God creates humanity as a potter creates a pot". In

Gender Epistemologies in Africa: Gendering Traditions, Spaces, Social Institutions, and Identities, edited by O. Oyewùmi, 199-222. New York: Palgrave Macmillan, 2011.

Schiffer, M. The Portable Radio in American Life. Tucson \& London: University of Arizona Press, 1991.

Sellet, F. "Chaine operatoire: the concept and its applications". Lithic Technology 18, no. 1 (1993): 106-112.

Soper, R. "A survey of the irrigation system of the Marakwet". In Kerio Valley Past Present and Future, edited by B.E. Kipkorir, R.C. Soper and J.W. Ssennyonga, 75-95. Nairobi: Institute of African Studies, University of Nairobi, 1983.

Spear, T. 'Being 'Maasai' but not 'people of cattle': Arusha agricultural Maasai in The nineteenth century”. In Being Maasai: Ethnicity and Identity in East Africa, edited by T. Spear and R. Waller, 120-136. London: James Currey, 1993.

Spear, T. Mountain Farmers: Moral Economies of Land and Agricultural Development in Arusha and Meru. Oxford: James Currey, 1997.

Spindel, C. "Potters and pots". In Iron, Gender, and Power: Rituals of Transformation in African Societies, edited by E. Herbert, 200-218. Bloomington and Indianapolis: Indiana University Press, 1993.

Ssennyonga, J. The Marakwet irrigation system as a model of a systems-approach to water management. In Kerio Valley: Past, Present and Future, edited by B.E. Kipkorir, R.C. Soper and J.W. Ssennyonga, 96-111. Nairobi: Institute of African Studies, University of Nairobi, 1983.

Thomas, N. "The case of the misplaced ponchos: speculations concerning the history of cloth in Polynesia". Journal of Material Culture 4, no. 1 (1999): 5-20. 
Tignor, R. Colonial Transformation of Kenya: The Kamba, Kikuyu and Maasai from 1900-1939. Princeton: Princeton University Press, 2015 [1976].

Tilley, C. “Objectification”. In Handbook of Material Culture, edited by C. Tilley, W. Keane, S. Küchler, M. Rowlands and P. Spyer, 60-73. London: Sage, 2006.

Van Zwanenberg, R. M. A. Colonial Capitalism and Labour in Kenya 1919-1939. Nairobi: East African Literature Bureau, 1975.

Watson, E. "Agricultural intensification and social stratification: Konso in Ethiopia contrasted with Marakwet". In Islands of Intensive Agriculture in East Africa, edited by M. Widgren and J.E.G. Sutton, 49-67. Oxford: James Currey, 2004.

Welbourn, D. Endo Knowledge, Technology and Power: The Social Construction of Endo Material Culture through Age, Gender and Authority. PhD diss., University of Cambridge, 1984.

Wilmsen, E. Land Filled with Flies: A Political Economy of the Kalahari. Chicago: University of Chicago Press, 1989.

Wolf, E. Europe and the People Without History. Berkley \& London: University of California Press, 1982.

\section{Figures}

Figure 1. Map of the Elgeyo escarpment in western Kenya.

Figure 2. Illustration of the Sibou ceramic assemblage. 1. Kipsagat - used for the preparation of medicinal roots and plants 2. Kitebar - used for general domestic cooking 3. Kire - used for cooking vegetables, porridge, and ugali (a porridge or dough like staple dish made from either maize, millet or sorghum flour), and occasionally medicinal roots and plants 4 . Kapepka - used for general domestic cooking 5. Terepar - used for general domestic cooking, and often for cooking large portions of ugali 6 . Terre ma' - used for alcohol brewing and consumption at 
ceremonies 7. Morr bo terr - used for alcohol brewing 8. Kossum - Used for the storage of drinking water in homesteads.

Figure 3. Selected photographs of Chemet cave. Above left - Chemet cave interior, looking outwards. Below left - Chemet cave exterior, looking inwards. Right - the source of red mun close to Chemet cave.

Figure 4. Terre ma' on display at Nairobi National Museum as part of the 'language of clay’ exhibition, 2016.

Figure 5. Pots in use at Sibou in 2015. Above left — kossum, below left — kapepka, right — kire and kipsagat. 